\title{
Study on Spatio- Economic Relationship of Industries in Greater Nagpur Area
}

\author{
Rashmi S. Waghmare
}

\begin{abstract}
This paper is an attempt to address the spatioeconomic relationship of the industries and the general theory and challenges relating to the industrial location. The existing industrial performance of the region, the top performing and lagging industries of the region along with the spatial analysis were ascertained, using tools like shift share analysis, location quotients and delineation tools such as land and economic suitability matrix. Nagpur is becoming one of the major nuclei for Industrial Growth in the State of Maharashtra and the country in a larger perspective. Thus, this paper tries to represents the regional industrial environment through proper industrial mix where the enterprises can make profit by determining spatial margin to profitability. It can be used as the foundation for enterprises to select locations and type of industries in the overall scope of industry allocation.
\end{abstract}

Keywords--- Industry Allocation, Inter Industrial Linkages, Location Quotients, Shift and Share Analysis, SpatioEconomic Relationship

PREAMBLE - "WHAT ARE THE REASONS FOR THE LOCATION OF A PARTICULAR ENTERPRISES OR INDUSTRY IN A SPECIFIC AREA? IS IT JUST A SNAP DECISION OR IS THERE MORE OF A SCIENCE TO THE DECISION?"

BY ALFRED WEBER [1]

\section{INTRODUCTION}

$\mathrm{A}$ MONGST the policies for overall economic development industries plays an important role. Industrialization is one of the major solutions for raising the level of economy and providing employment opportunities. It focuses both on the region and the people's creativity, skill and talent (Issard, 1960). Economic factors play a vital role in the growth of the industries such as availability of land, raw materials, labour, transport and infrastructure. The industrial development is primarily linked with increasing investment, generating employment and socio-economic development of the region. For the sustainable industrial growth, there is a need to develop the industries in all the three aspects (i.e. economic, environment and social) and positioned in a spatial location allocation framework.

Nagpur remains a city with tremendous economic potential. Today, due to the combination of changed political will and history of cordial industrial relations Nagpur is on the brink of rapid economic development. Being uniquely situated at the geographical centre of India, it is becoming one of the

Rashmi S. Waghmare, Deputy Planner in Mumbai Metropolitan Region Development Authority (MMRDA), Bandra Kurla Complex, Bandra East, Mumbai, India-400051. E-mail:rashmiw6021@gmail.com major nuclei for Industrial Growth in the State of Maharashtra and the country in a larger perspective. Currently, industrial growth is more concentrated to the Butibori industrial zone which lies close to the NH-7. Butibori industrial area is serving as one of the major venues for a large number of industries and is getting itself established as a five star industrial zone.

A group of constantly developing industries located around the Nagpur urban areas has induced the further concentration of industries and thus affecting the surroundings. Hence, there is a need to avoid excessive concentration and haphazard development of industries for the sustainable industrial growth. Thus, this paper puts up the study on the spatioeconomic relationship of the industries in Greater Nagpur area to identify the constantly developing industries in and around Nagpur region, thereby enhancing inter-industrial linkages, spatial distribution of industries and hence developing the investment scenario by representing the regional industrial environment for the sustainable industrial growth.

\section{IDENTIFICATION OF MAJOR ISSUES}

Industrial progress cannot be achieved easily as it is preconditioned by several factors. The important ones being availability of land, capital, industrial enterprises, labour, availability of raw materials and good markets, speedy and efficient means of transportation. To understand the present scenario of the industrial development in Nagpur region certain studies were done. Based on the study some of the major issues are identified both at the regional and local level (Table 1).

Table 1: Issues of Concern

\begin{tabular}{|l|l|}
\hline Issues & Description \\
\hline Sectoral issue & $\begin{array}{l}\text { Contribution of per capita income to Gross } \\
\text { Domestic Product (GDP) in Maharashtra state } \\
\text { is more in service sector as compared to } \\
\text { manufacturing sector. [2] }\end{array}$ \\
\hline $\begin{array}{l}\text { Category mix/ } \\
\text { Imbalance issue }\end{array}$ & $\begin{array}{l}\text { In the Nagpur region almost all industrial area } \\
\text { fall under the D or D+ category which } \\
\text { reflects a very low level of industrial } \\
\text { development. [3] }\end{array}$ \\
\hline $\begin{array}{l}\text { Environment } \\
\text { issue }\end{array}$ & $\begin{array}{l}\text { From the pollution control board report it is } \\
\text { found out that maximum Large Scale } \\
\text { industries are red in nature in the Nagpur } \\
\text { Region. [4] }\end{array}$ \\
\hline $\begin{array}{l}\text { Composition } \\
\text { Issue }\end{array}$ & $\begin{array}{l}\text { Nagpur region has mainly SSI (Small Scale } \\
\text { Industries) which constitutes 96\% of total } \\
\text { industries, while MSI (Medium Scale } \\
\text { Industries) and LSI (Large Scale Industries) } \\
\text { contribute only 2\% each. [4] }\end{array}$ \\
\hline Location issue & \begin{tabular}{l} 
Impact of the newly proposed industrial belt \\
\hline
\end{tabular}
\end{tabular}




\begin{tabular}{|l|l|}
\hline in Butibori area. \\
The distance from Butibori industrial area to \\
the Nagpur city which is the major urban \\
center with 20.52 Lakhs population (i.e 50\% \\
of Nagpur district) is approx. 30 Km and \\
hence, it results in increased trip length for \\
the major commuter.
\end{tabular}

So, in a bid to build a competitive environment; industries $\&$ their ancillaries have to be promoted in clusters, based on the availability of raw materials, skilled labour, and market potential and through proper industrial mix.

\section{INDUSTRIAL LOCATION IN AND AROUND NAGPUR REGION}

Maharashtra Industrial Development Corporation (MIDC) classifies industrial areas into 4 types. They are five star industrial area, Major industrial area, and Mini industrial area and Growth centers. Amongst all the industrial areas in and around Nagpur region, four major industrial zones are identified as these nodes attain special significance in terms of their proximity to the highly urbanized region (mainly Nagpur urban area) and adjoining industrial clusters. These areas are Butibori industrial area, Kalmeshwar industrial area, Hingna industrial area and Wardha industrial area as shown in Figure 1. Proposed project of MIHAN SEZ area is also taken into consideration as it will create huge impact on the Nagpur regional economic development in the years ahead.

From the primary survey and expert opinion survey it was found that the factors that make Nagpur an ideal investment destination are: i) availability of affordable land; ii) availability of qualified manpower at competitive prices; iii) well connectivity to the rest of the country; iv) upcoming international airport; v) history of cordial industrial relations; vi) easily available abundant natural resources like forest and minerals.

\section{LITERATURE STUDY}

The study on spatial distribution of industries can be traced back to the Industrial Location Theory [5] of Weber, a German economist. Alfred Weber formulated a theory of industrial location in which an industry is located where the transportation costs of raw materials and final product is a minimum. However, Weber's model is a supply side model, and assumes static demand in either a single market or to a single distribution point to multiple markets. Further, David Smith's (1981) extended the Weber's model by assuming equal production costs across producers. This model is called the Weberian Least Cost Model. However, this is clearly not the case in the real world. Variations in scale of production and technology (how land, labour, capital, natural resource, and managerial inputs are transformed into output) can lead to variations in production costs. Hence, scale and technology factors can influence optimal location.

In August Losch's (1954) location theory [6], the main focus is on the economic aspect of the region. He proposed that each product has a specific demand curve, which varies according to the demographic density and the cost of transportation to the production centre brought upon the consumer. This approach was ignored by the Weber's least cost theory. Losch concludes that demand is more elastic in an industrial economy than in an agricultural economy, and supply is more elastic in an agricultural economy. Local differences in transport rates are considered in this theory.

Various location theories and economic models [7] helped to identify factors to establish the suitable locations for the new industries. Factors that influence where an industry/firm will choose to locate were determined. This can be classified under

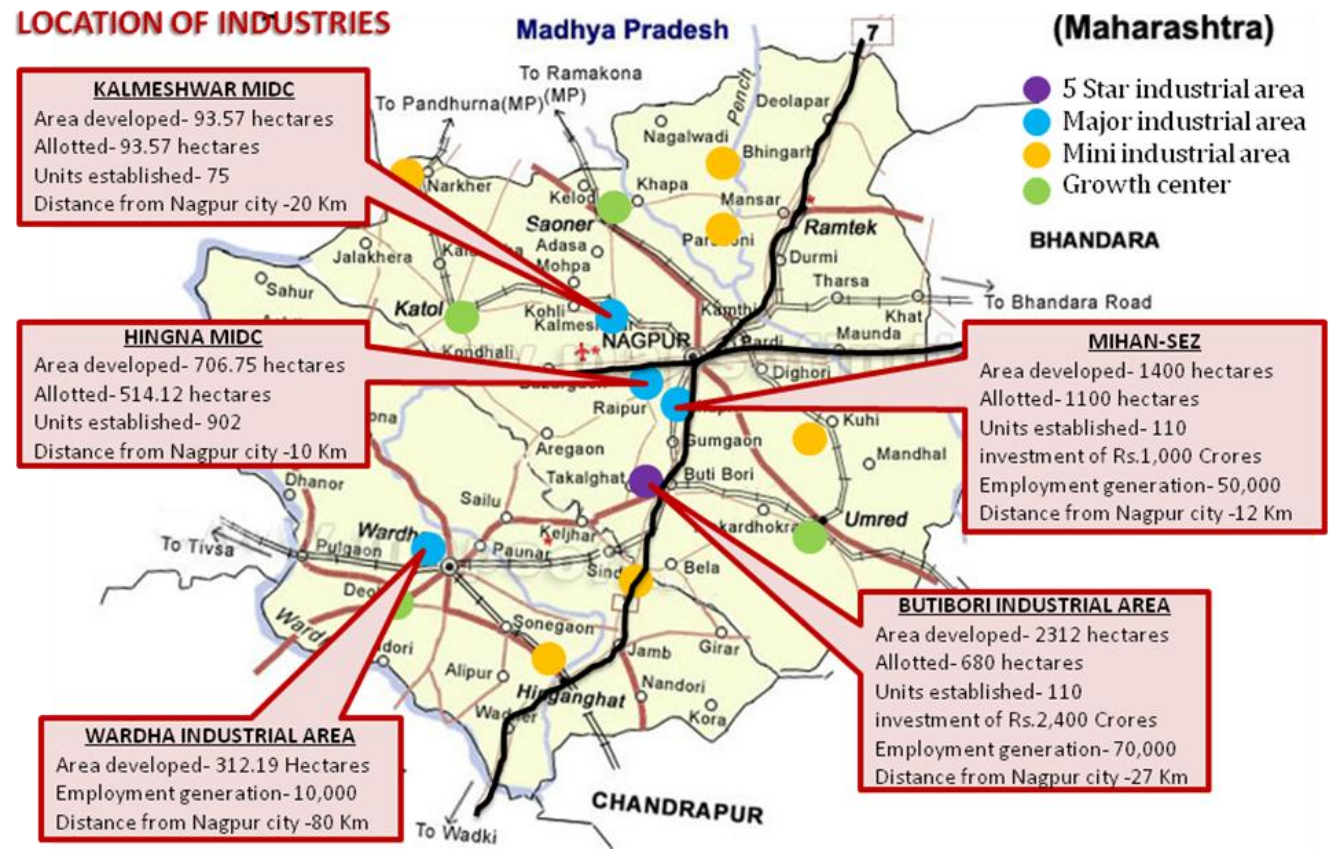

Figure 1: Location of Industries in and Around Nagpur City [3] 
two levels. One is spatial level and other is strategic level as shown in table 2 . The following could all be considered as important but for some industry/firm, some of the factors will be more important than others.

Table 2: Factors Affecting Location Decisions

\begin{tabular}{|c|c|}
\hline At spatial level & At strategic level \\
\hline $\begin{array}{ll}\text { - } & \text { Nearness to a Supply of Raw } \\
\text { - } & \text { Materials } \\
\text { - } & \text { Nearness to Market } \\
\text { - } & \text { Nearness to a Supply of Labour } \\
\text { - } & \text { Proximity of Other Businesses - } \\
\text { - } & \text { External Economies of Scale } \\
\quad \text { Transport and Communication } \\
\text { Services }\end{array}$ & $\begin{array}{ll}\text { - } & \text { The Reputation of } \\
\text { an Area } \\
\text { - } \\
\text { - } \\
\text { - Compentives } \\
\text { - Opportition } \\
\text { Expansion }\end{array}$ \\
\hline
\end{tabular}

\section{SCENARIO ANALYSES}

In order to emphasize on the scenario analysis of the Nagpur region, models were used like shift and share analysis, location Quotients and land and economic suitability matrix. The aim of this approach is to know the potential location for the industrial setup, sectoral and spatial share of the industries and competitiveness of industries within the region. The spacio- economic relationship of the industrial area in the Greater Nagpur area is also determined. The two major criteria for analysis are taken as the total no. of establishment and total no. of employment.

\subsection{At District Level}

The quotients for industrial location of the 6 districts in Nagpur region were obtained by determining the relationship between the employments and establishments with the population of the district. Location quotient indicates the concentration of employments or industries in a particular zone or location. Graph shows (Fig. 2) Nagpur, Bhandara and Gondia have high concentration of establishment and employment in accordance with its share at the region.

Figure 2: Graph Showing Location Quotients for Employment

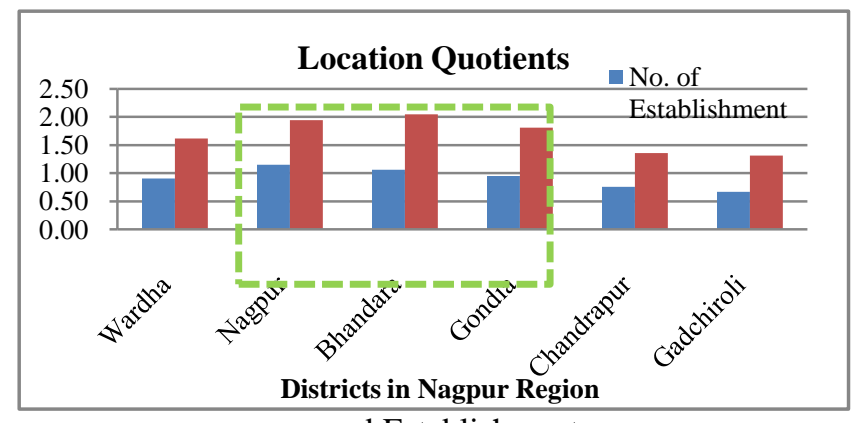

and Establishment

When these three districts were compared (Table 3) with respect to population, no. of employment \& no. of stablishment over the Nagpur region, it is observed that Nagpur District contributes the highest percentage of population along with the highest percentage share of employment and establishment.

Table 3: Table Showing the Total Population, Employment and Establishment in 3 Districts

\begin{tabular}{|c|c|c|c|c|c|c|}
\hline \multirow{2}{*}{ Districts } & \multicolumn{5}{|c|}{ \% over Nagpur Region } \\
\cline { 2 - 7 } & Population & \multicolumn{2}{|c|}{ Employment } & \multicolumn{2}{c|}{ Establishment } \\
\hline Nagpur & 4346000 & $39 \%$ & 545338 & $46 \%$ & 211049 & $44 \%$ \\
\hline Bhandara & 1154000 & $10 \%$ & 133924 & $11 \%$ & 59050 & $12 \%$ \\
\hline Gondia & 1218000 & $11 \%$ & 126700 & $11 \%$ & 55162 & $11 \%$ \\
\hline
\end{tabular}

Under shift and share analysis, the data from fourth and fifth economic Census, Maharashtra State were analyzed [8]. From these data a distinction between the top performing and lagging industries were made. Shift-share analysis is one way to account for the competitiveness of a region's industries and to analyze the local economic base. It shows how well the region's current industries are performing by systematically examining the national, regional and local industrial components [9]. The formula used for the calculation of shift and share [10] is as follows:

Differential Shift

$$
\mathrm{Dj}=\{[\Delta \mathrm{Xij} / \mathrm{Xij}(\mathrm{t})]-[\Delta \mathrm{XN} / \mathrm{XN}(\mathrm{t})]\} * \mathrm{X} \mathrm{ij}(\mathrm{t})
$$

Proportional Shift

$$
\begin{aligned}
& \mathrm{Pj}=\{[\Delta \mathrm{XiN} / \mathrm{XiN}(\mathrm{t})]-[\Delta \mathrm{XN} / \mathrm{XN}(\mathrm{t})]\} * \mathrm{X} \mathrm{ij}(\mathrm{t}) \\
& \text { Total Shift }
\end{aligned}
$$

$$
\mathrm{Sij}=[\Delta \mathrm{Xij}-\Delta / \mathrm{XN}(\mathrm{t})] * \mathrm{X} \mathrm{ij}(\mathrm{t})
$$

Where,

Xij(t)- Employment or no of establishment in 1998 at District level

XiN(t)- Employment or no of establishment in 1998 at Regional level

XN(t)- Employment or no of establishment in 1998 at State level

$\Delta \mathrm{Xij}=\mathrm{Xij}(\mathrm{t}+\mathrm{r})-\mathrm{Xij}(\mathrm{t})$ Where, $\Delta \mathrm{Xij}$ is change in the no. of employment or in no. of establishment from year 1998 to 2005 at district level.

The shift and share analysis (Fig. 3) yields that, at district level there was a positive share of number of manufacturing industry while its regional share is negative from year 1998 to 2005. It means there is more increase in manufacturing industries at the Nagpur district compared to the overall Nagpur region. But there is negative share of employment in manufacturing industry at the district level. It means even if numbers of manufacturing industries have increased, employment in the manufacturing sector has decreased. 


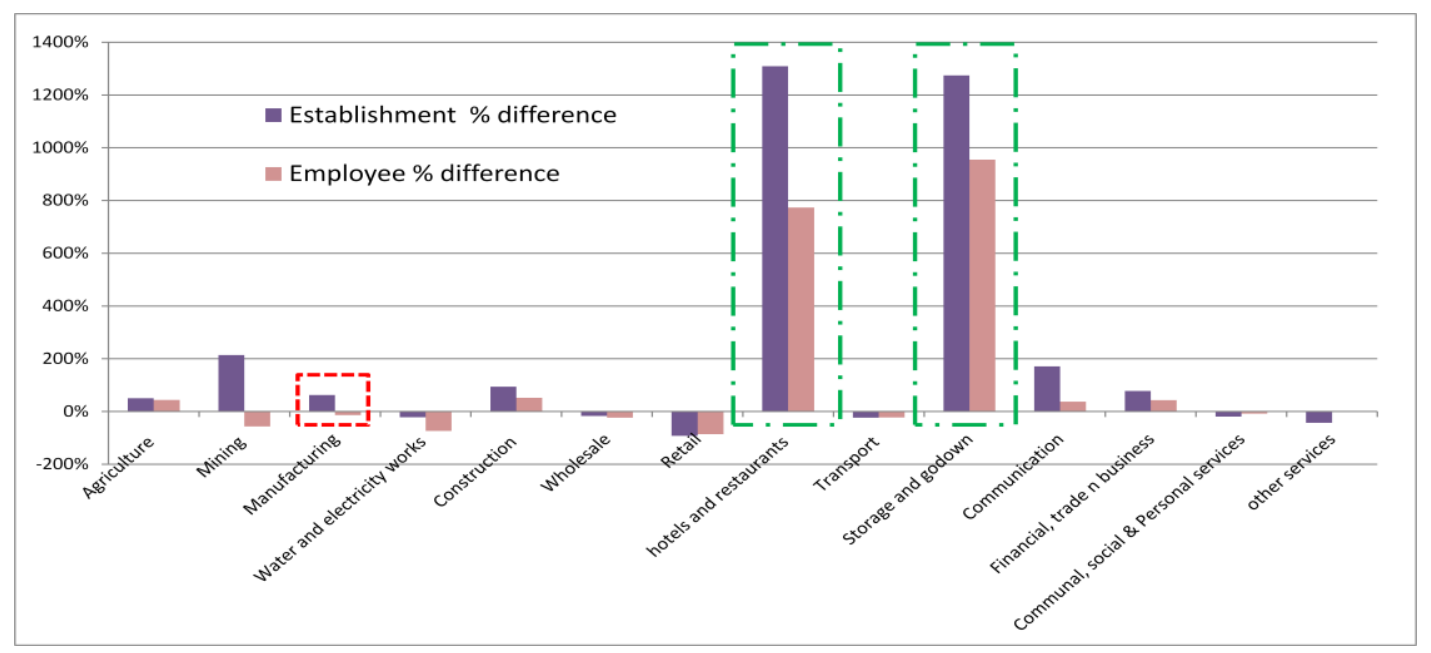

Figure 3: Economic Census Results- Industry Employment Mix at District Level (1998-2005) [11]

Hence, to understand the increase or decrease in number of various manufacturing industries and its employment generation the data from year 2006 to 2009 has been studied. All the manufacturing industries are classified under three heads-

i. Consumer goods industries

ii. Intermediate goods industries

iii. Capital goods industries

Consumer goods industries are mainly resource based downstream industries (like textile industry), intermediate industries are mainly upstream industries (like steel rolled industry) and capital goods industries are mainly capital intensive industries (like automobile industry and heavy industries).
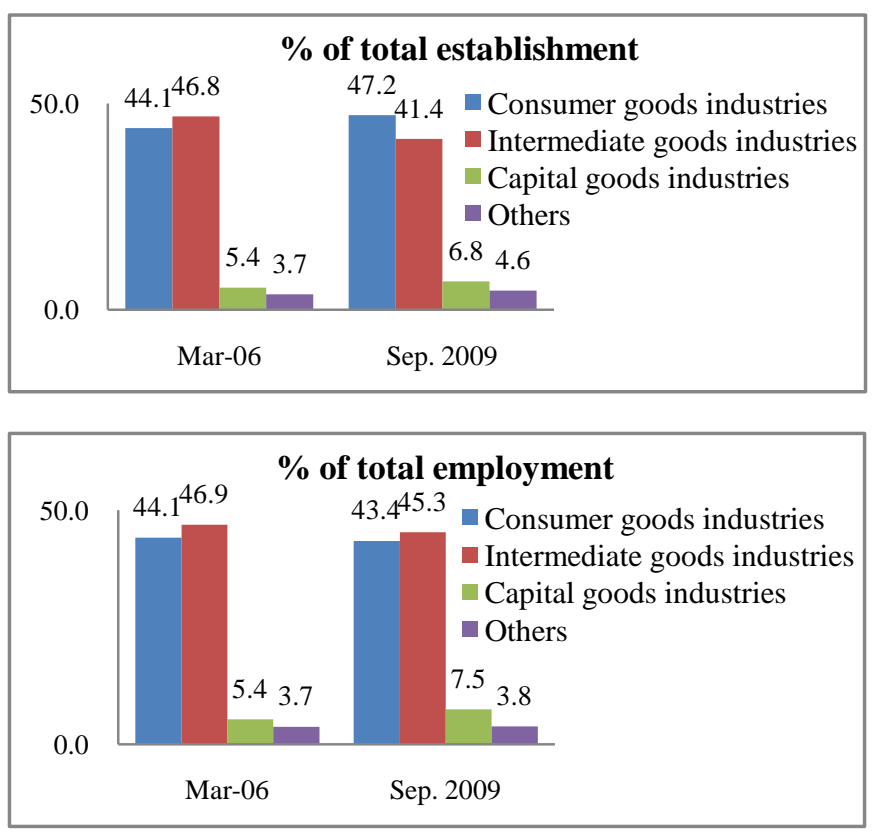

Figure 4: Percentage Total of Establishment and Employment as per the Classification of Industries
By considering percentage share of employment and establishment to the total value of respective criteria, Consumer goods industries and capital goods industries has shown the positive growth while the intermediate goods industries has shown declined trend both in terms of number and employment generation. Even if there was increase in consumer goods industries, the employment engaged in these industries were reduced. It indicates that employment generation is shifted towards the capital goods industries thus, affecting the local talent.

\subsection{Spatial Analysis at District Level}

Spatial analysis has been done combining the two matrixes [12]. One is the land suitability matrix and other is economic viability matrix to understand the spacio- economic relationship of industries in Nagpur district.

\subsubsection{Land Suitability Matrix}

Land suitability matrix is prepared by overlapping of Air pollution sensitivity matrix, Surface water sensitivity matrix and Ground water sensitivity matrix. After overlapping all these grid maps, a land suitability matrix (Fig. 3) was prepared. It is found that eastern and north eastern part of Nagpur district is more suitable for the agricultural activities as it has high water availability and has high fertile soil. While western and south western part is more suitable for nonagricultural activities. This area has plateau type of morphology and has shallow type of soil which is not suitable for agricultural activities. Even the concentration of waste land is high in this part which makes it more suitable for industrial development. 


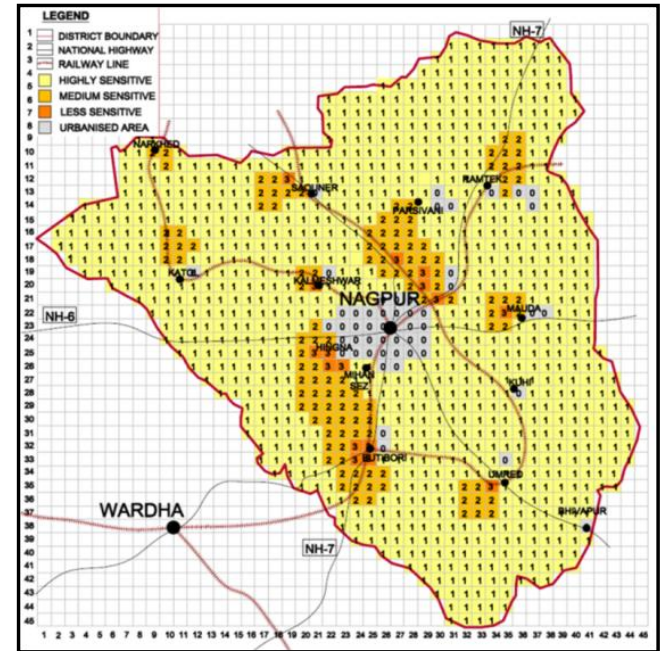

Figure 5a: Air Pollution Sensitivity Matrix

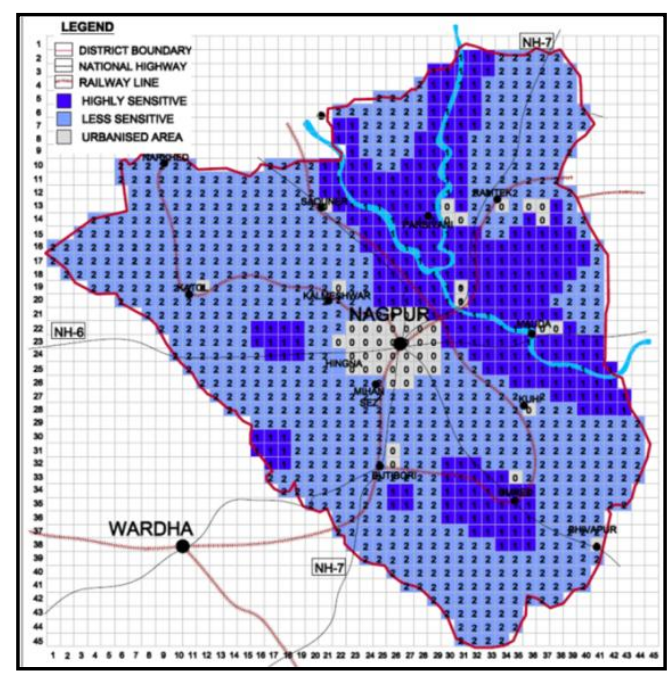

Figure 5b: Surface water pollution sensitivity matrix

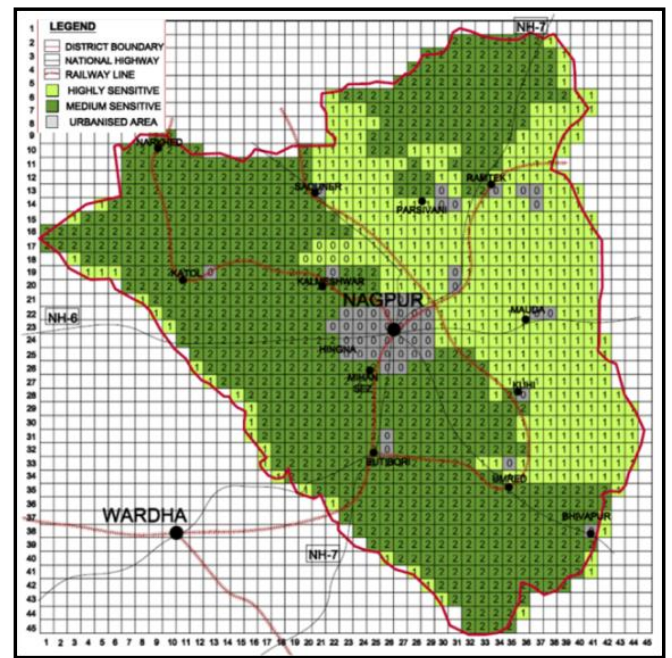

Figure 5c: Ground water sensitivity matrix

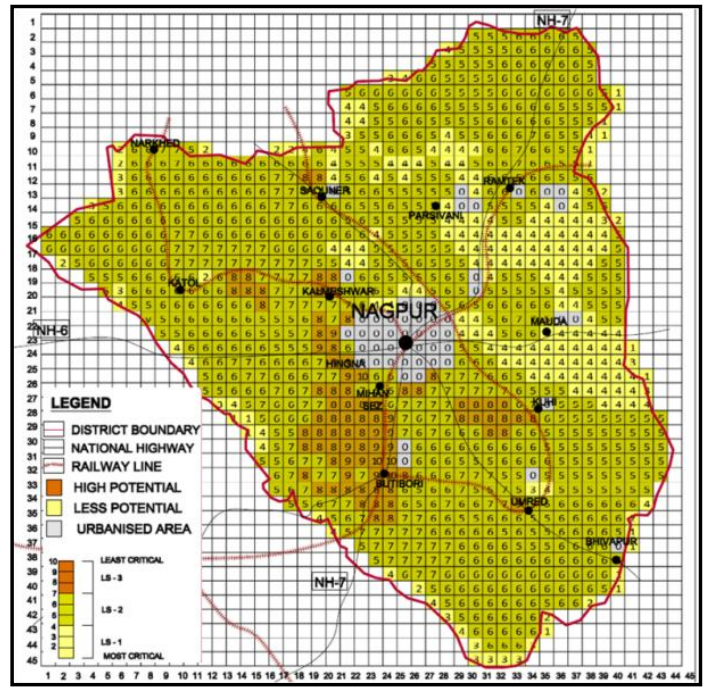

Figure 5d: Resultant of Fig. 5a, 5b and 5c

\subsubsection{Economic Suitability Matrix}

An economic suitability matrix is prepared by overlapping terrain map, resource map and transportation map. The multicriteria analysis was used to arrive at the economic suitability zones. After overlapping these three maps, economic suitability matrix (Fig. 4) was prepared. It is observed that the availability of minerals are more towards the northern part of Nagpur district but due to the higher concentration of settlements towards the northern part it results in higher land value near the more urbanized area. So southern part of Nagpur district is more suitable for industrial location. Even the rail linkages towards the southern part are well laid which will help to establish strong inter-industrial relationship between the industries.

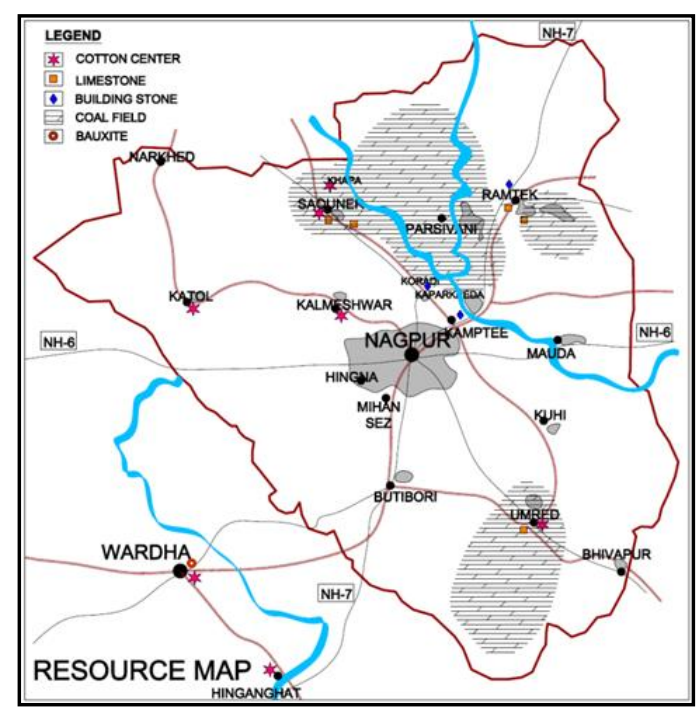



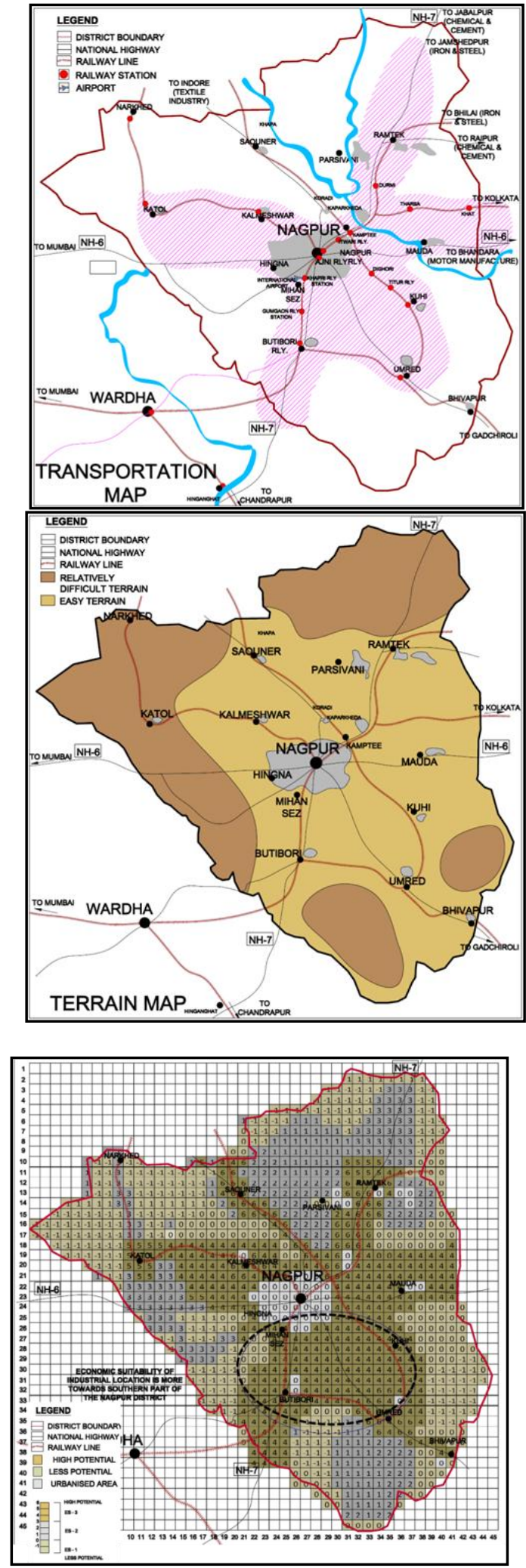

Figure 6: Resultant of Resource Map, Transportation Map and Terrain Map

\subsection{At local Level}

Again, shift and share analyses was performed to understand the performance of the identified industrial area i.e. Kalmeshwar industrial area, Hingna industrial area,
Butibori industrial area and Wardha industrial area. The visible result for the local level (Fig. 5) shows that the Butibori industrial area has positive share at local level as well as at regional level, both in the case of establishment and employment. Though the rest of industrial areas have shown an increase in employment generation, the total increase in establishment is less.

\begin{tabular}{|l|c|c|c|}
\hline \multicolumn{4}{|c|}{ Establishment Criteria } \\
\hline \multicolumn{1}{|c|}{ Areas } & $\begin{array}{c}\text { Local share } \\
(\mathrm{D})\end{array}$ & $\begin{array}{c}\text { District share } \\
(\mathrm{P})\end{array}$ & $\begin{array}{c}\text { Regional share } \\
(\mathrm{S})\end{array}$ \\
\hline Kalmeshwar & $-10 \%$ & $9 \%$ & $-12 \%$ \\
\hline Hingna & $-87 \%$ & $74 \%$ & $-118 \%$ \\
\hline Butibori & $5 \%$ & $10 \%$ & $39 \%$ \\
\hline Wardha & $-8 \%$ & $7 \%$ & $-9 \%$ \\
\hline
\end{tabular}

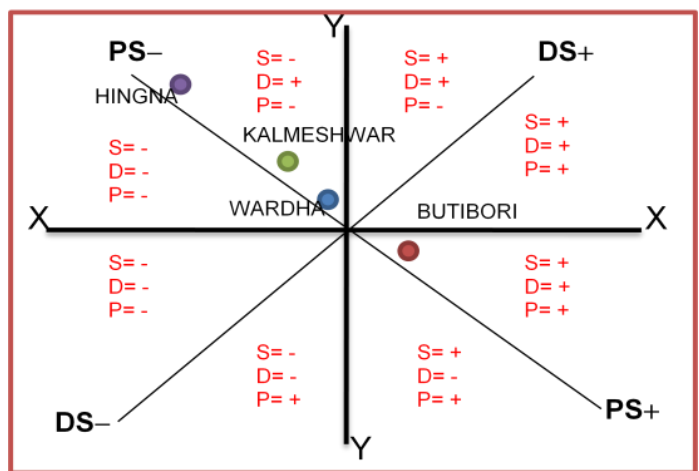

\begin{tabular}{|l|c|c|c|}
\hline \multicolumn{4}{|c|}{ Employment Criteria } \\
\hline \multicolumn{1}{|c|}{ Areas } & $\begin{array}{c}\text { Local share } \\
(\mathrm{D})\end{array}$ & $\begin{array}{c}\text { District share } \\
(\mathrm{P})\end{array}$ & Regional share (S) \\
\hline Kalmeshwar & $8 \%$ & $-11 \%$ & $-2 \%$ \\
\hline Hingna & $46 \%$ & $-62 \%$ & $-11 \%$ \\
\hline Butibori & $42 \%$ & $-24 \%$ & $108 \%$ \\
\hline Wardha & $3 \%$ & $-3 \%$ & $5 \%$ \\
\hline
\end{tabular}

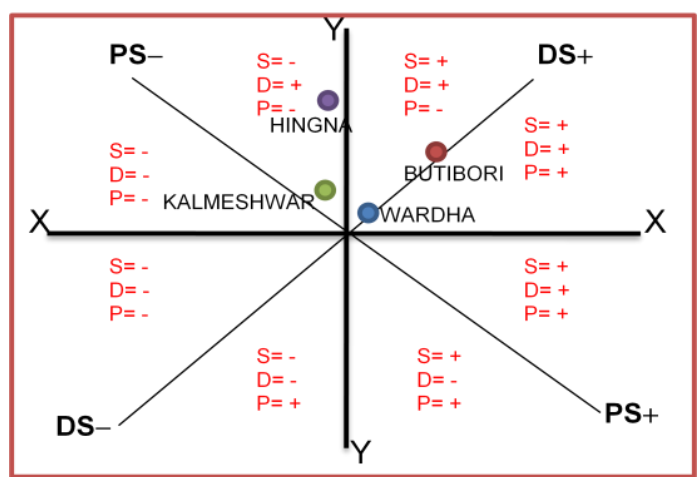

Figure 7: Best Industrial Location through Shift and Share Analysis by Considering Establishment Criteria (above) and Employment Criteria (below)

The data obtained from the secondary source, from the statistical department for each major industrial zone of study area, was analyzed. Table 4 shows that there is an increase in almost all types of manufacturing units in the Butibori industrial area from year 2005-06 to 2008-09 [13] except capital based industries, while in Kalmeshwar, Hingna and 
Wardha capital-based industries have been coming up in the past 2-3 years.

Table 4: Increased or Decreased of Industries Based on the Classification of Industries

\begin{tabular}{|l|c|c|c|c|}
\hline & Kalmeshwar & Hingna & Butibori & Wardha \\
\hline $\begin{array}{l}\text { Consumer goods } \\
\text { industries }\end{array}$ & $0 \%$ & $0 \%$ & $43 \%$ & $0 \%$ \\
\hline $\begin{array}{l}\text { Intermediate } \\
\text { goods industries }\end{array}$ & $0 \%$ & $0 \%$ & $88 \%$ & $0 \%$ \\
\hline $\begin{array}{l}\text { Capital goods } \\
\text { industries }\end{array}$ & $6 \%$ & $1 \%$ & $-49 \%$ & $19 \%$ \\
\hline $\begin{array}{l}\text { Others(power } \\
\text { supply } \\
\text { industries, } \\
\text { telecommunicati } \\
\text { on, import } \\
\text { export trading } \\
\text { and machinery } \\
\text { servicing) }\end{array}$ & $11 \%$ & $-15 \%$ & $886 \%$ & $0 \%$ \\
\hline $\begin{array}{l}\text { Service } \\
\text { industries }\end{array}$ & $50 \%$ & $0 \%$ & $36 \%$ & $0 \%$ \\
\hline
\end{tabular}

Also, Table 4 indicates that there is decrease in the manufacturing units in Hingna industrial area. The reason might be the higher number of the closed units, which was found during the primary survey.

\subsection{Spatial Analysis at Local Level}

Based upon the secondary data for the year 2008-09, the location preferences for the above mentioned four areas were worked out by the two methods. One is weighted-factor scoring model and other is dimensional analysis technique. The weightage for each criterion was decided based on some basic study through literature and by understanding through primary survey and expert opinion survey.

Table 5: Weighted Factor Scoring Model

\begin{tabular}{|c|c|c|c|c|c|c|c|c|c|}
\hline $\begin{array}{c}\text { STATISTCAL } \\
\text { DATA }\end{array}$ & L1 & L2 & L3 & L4 & $\begin{array}{c}\text { Weig } \\
\text { htage } \\
\text { (Wi) }\end{array}$ & Wi*L1 & Wi*L2 & Wi*L3 & Wi*L4 \\
\hline Items & $\begin{array}{c}\text { Kalmeshwa } \\
\mathrm{r}\end{array}$ & $\begin{array}{c}\text { Hingn } \\
\mathrm{a}\end{array}$ & Butibori & Wardha & & & \\
\hline No of plots alloted & 153 & 1525 & 1636 & 343 & 0.10 & 15.30 & 152.50 & 163.60 & 34.30 \\
\hline Unit under production & 147 & 1208 & 460 & 128 & 0.10 & 14.70 & 120.80 & 46.00 & 12.80 \\
\hline $\begin{array}{c}\text { Unit under } \\
\text { construction }\end{array}$ & 2 & 36 & 232 & 17 & 0.10 & 0.20 & 3.60 & 23.20 & 1.70 \\
\hline Total no. of sick units & 0 & 198 & 90 & 30 & 0.05 & 0.00 & 9.90 & 4.50 & 1.50 \\
\hline $\begin{array}{c}\text { Annual turnover in } \\
\text { Crs) }\end{array}$ & 1007.73 & 2542.5 & 3960 & 20 & 0.30 & 302.32 & 762.75 & 1188.00 & 6.00 \\
\hline $\begin{array}{c}\text { Total investment in } \\
\text { Crs)) }\end{array}$ & 71.68 & 1715.4 & 5060 & 235 & 0.15 & 10.75 & 257.31 & 759.00 & 35.25 \\
\hline total employment & 5236 & 29200 & 18645 & 1800 & 0.20 & 1047.20 & 5840.00 & 3729.00 & 360.00 \\
\hline
\end{tabular}

Above method showed the variant result with respect to location preference. Hence, considering the two factors i.e. employment and annual turnover, GIS contour map has been created for both the factors. After overlapping the two contour maps Fig 8 shows the resultant map. Here, the result shows that Butibori has high potential for industrial development followed by Hingna. Even though Hingna has shown negative growth at district and regional level, it has the potential at the local level with respect to employment generation. 
Table 6: Dimensional Analysis Technique

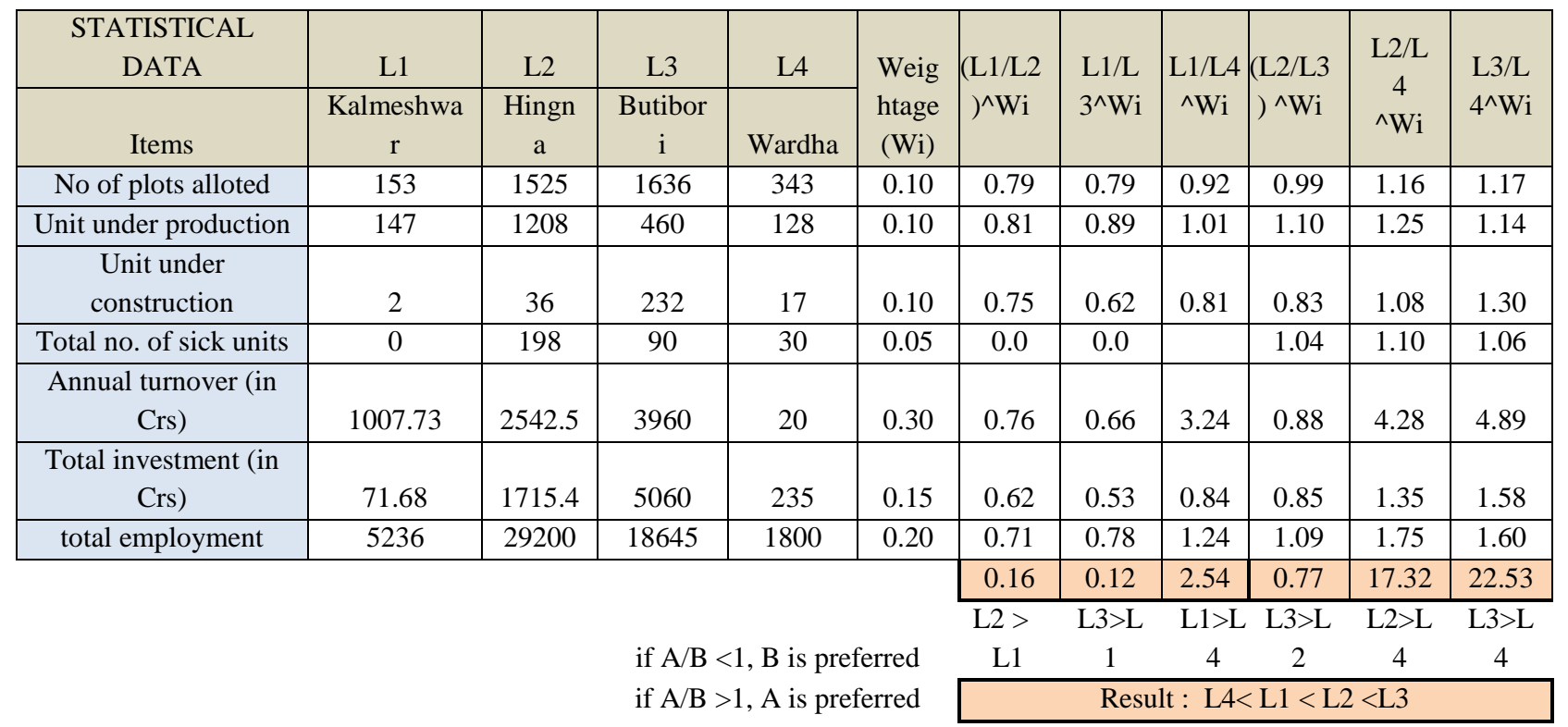

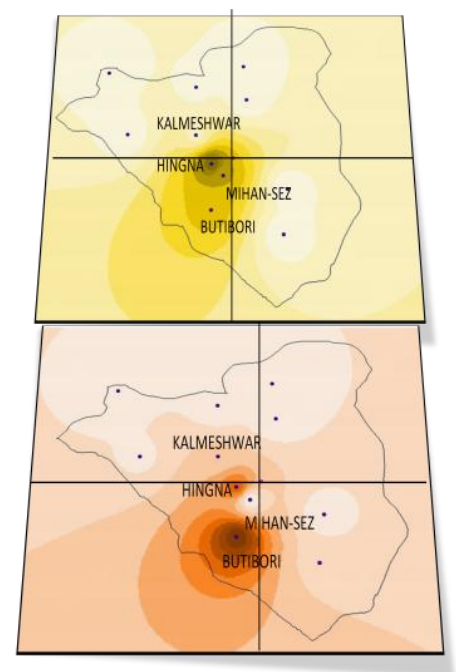

GIS contour map for

Employment generation

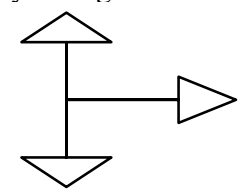

GIS contour map for Annual turnover

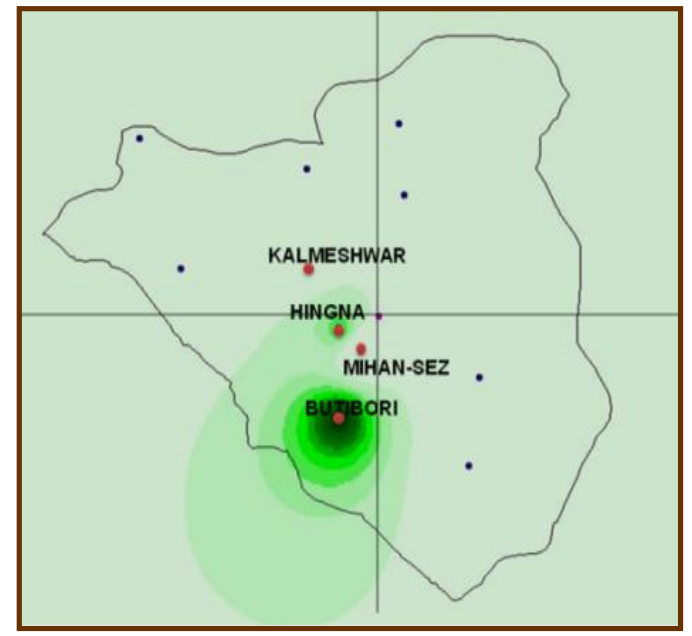

Figure 8: Resultant GIS Contour Map of Two Factors-Employment and Annual Turnover

\section{PROPOSALS}

The analysis helped to understand the entire existing industrial scenario in and around greater Nagpur area. Based on this study, an inter-industrial linkages flow chart (Figure 9) for the upstream, downstream and service industries supporting the manufacturing industries were worked out. It shows the link between various types of the downstream industries with the upstream industries which helped to establish the right industrial mix. Then, industries present in the different industrial locations were identified to understand the interdependency of types of industries within the industrial zone in the Nagpur region, for proper industrial clustering. Thus, the spatial distribution of the industries around the greater Nagpur area is denoted as shown in Figure 10 below. 


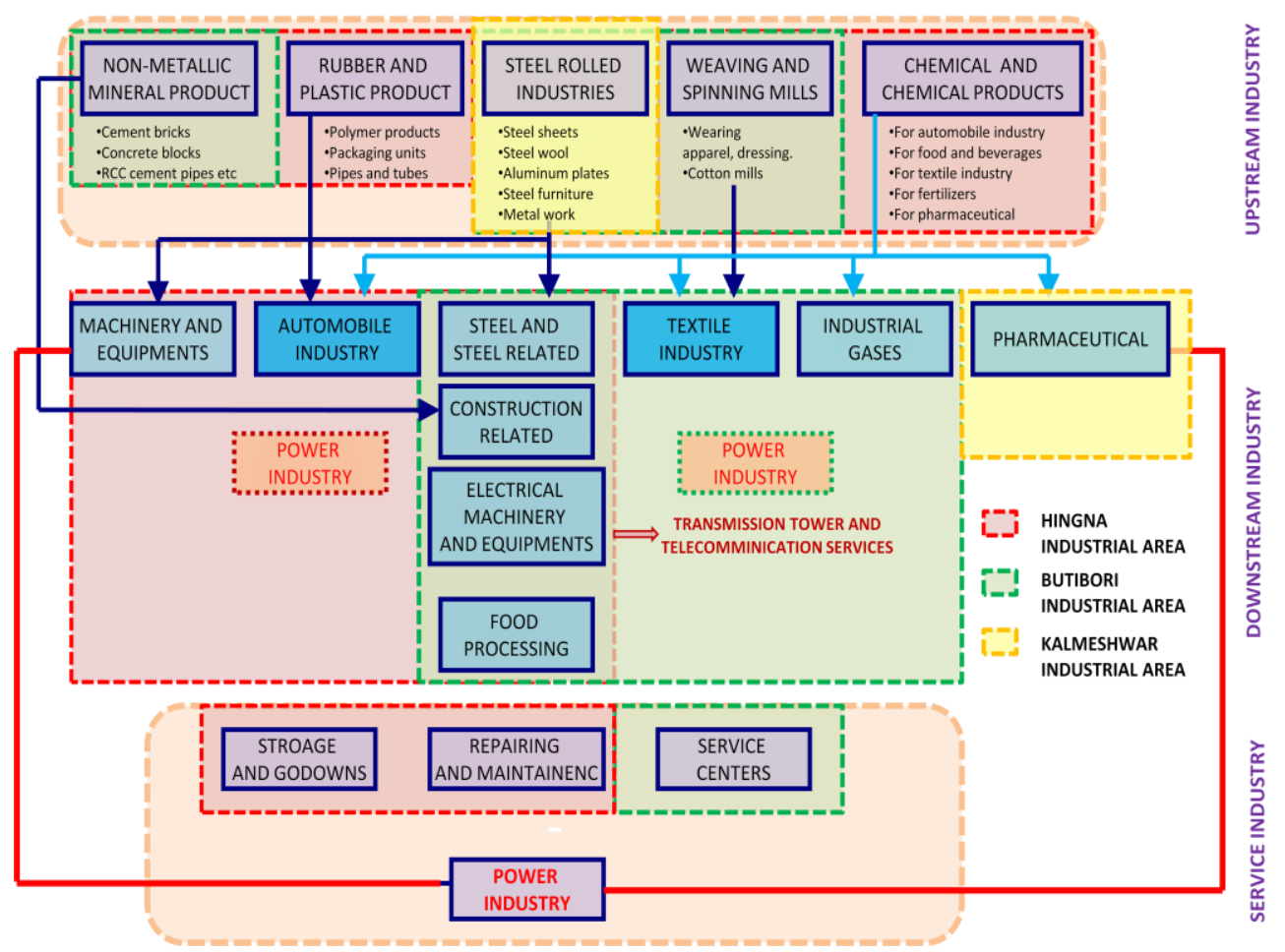

Figure 9: Inter - Industrial Linkages
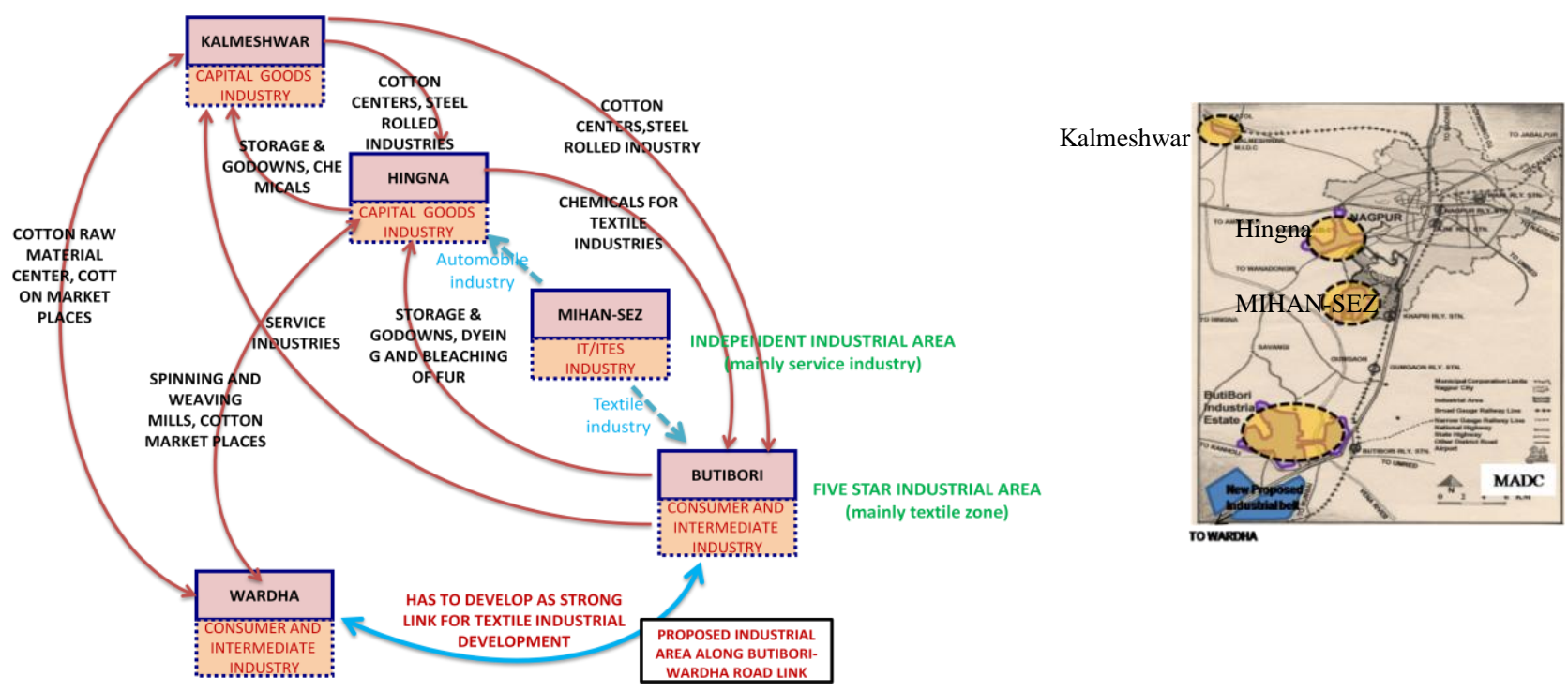

Figure 10: Flowchart Showing the Interdependency of Different Industrial Areas

\section{CONCLUSIONS}

Various factors help to determine the concentration of the new industries in the region. It's not only the availability of raw material, nearness to market and availability of employment in the region but the performance of the existing industries, local economic base and spatial distribution of surrounding industries also have a great influence on the decision of setting up any industrial zone in the city. Based on the above analysis, this paper concludes that the Major industrial areas in the Greater Nagpur region have great potential to enhance the Nagpur's local and regional economy and to provide high employment opportunity, thus improving the overall lifestyle. The shift -share analysis and location quotient has provided a simple, straightforward approach in separating out the state and industrial contributions from local growth and hence, proved useful for targeting industries that might offer significant future growth opportunities. Also, the land and economic suitability matrix has provided easy way in identifying the suitable spatial location for the industrial zone. Thus, the spatio-economic relationship of industries through proper industrial mix will not only foster the regional 
economic growth but also foster the progress of region into a domain of desired urbanization.

\section{ACKNOWLEDGMENT}

I would like to express my heartfelt gratitude to my mentor Prof. Joy Sen, Assistant Professor at Indian Institute of Technology, Kharagpur for his valuable guidance throughout this project, without which this work would not have been possible. His knowledge of regional planning and programming and considerable experience in the same helped me at every stage to lay a strong foundation throughout my project work.

\section{REFERENCES}

[1] Weber, Theory of Industrial Location, Beijing: the Commercial Press, 1997.

[2] Government of Maharashtra, "Handbook of Basic Statistics of Maharashtra," [Online]. Available: http://mahades.maharashtra.gov.in/. [Accessed March 2010].

[3] Maharashtra Industrial Development Corporation (MIDC), " Investment destination, Industrial areas," [Online]. Available: http://www.midcindia.org/Pages/IndustrialPage.aspx. [Accessed March 2010].

[4] Maharashtra pollution Control Board (MPCB), "Industry Statistics," year 08-09. [Online]. Available: http://mpcb.gov.in/indstat/categorywise2009.php. [Accessed March 2010].

[5] W. Issard, Location and Space-Economy, MIT press, 1960.

[6] Losch, The Economics of Location, Yale University Press, 1954.

[7] L. Needleman, Regional analysis, Penguin modern economics, 1968.

[8] Directorate of Economics and statistic, Fourth and Fifth Economic Census, Maharashtra state. Mumbai, Maharashtra state. Mumbai: Govt. of Maharashtra, 1998 and 2005.

[9] M. Rahman, " Location allocation of Special economic zone: a case study of Haldia," Dissertation, IIT, Kharagpur, MCP-08/2007.

[10] K.A. Silvers, Urban planning Analysis: methods and models, New York: John Wiley and Sons Ltd., 1974.

[11] Directorate of Economics and statistic, "Economic Census of Maharashtra," Govt. of maharashtra, Mumbai, 2008-09.

[12] P. Ghosh, "Zoning Atlas for sitting of industries for korbha district, Chattisgarh," Dissertation, IIT, Kharagpur, MCP $=08 / 15$.

[13] District Collector, "District socio-economic review of Nagpur district," Nagpur, 2005-06 and 2008-09.

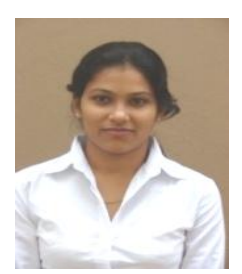

Rashmi S. Waghmare, Female, Nagpur, Maharashtra, India, DOB-30 Sept. 1985. Educational Background: Masters in City Planning (MCP) from Indian Institute of Technology (IIT), Kharagpur, West Bengal, India in year 2010 and Bachelors in Architecture from Vishveswaraya National Institute Technology (VNIT), Nagpur, Maharashtra, India in year 2008. Past work Experience: 1) HCPDPM Design and Project Management Pvt. Ltd. at Ahmedabad, Gujrat, India as a Junior Planner for 7 months (June 2010 to Jan 2011). 2) GTZ-Deutsche Gesellschaft für Technische Zusammenarbeit, Indo-German Environment Programme (ASEM), Panchsheel Park, New Delhi, India as trainee Planner for 2 months (June 2009 to August 2009). 3) Design Group India at Andheri (W), Mumbai , India as trainee Architect for 6 months (June 2007 to Dec 2007). Current job: Deputy Planner in Mumbai Metropolitan Region Development Authority (MMRDA), Bandra Kurla Complex, Bandra East, Mumbai, India since Jan. 2011(duration: 1 year and 10 months). Memberships in professional societies: Council of Architecture (CoA) Reg. No. CA/2009/46671 and registered member of Institute if Town Planners, India (ITPI). Publication: Waghmare R., "Strategy for location allocation plan for industries in Greater Nagpur area," ," in International Conference on Advances in Architecture and Civil Engineering(AARCV), Coimbatore, India, pp. 666-672, 2012. (E-mail:rashmiw6021@gmail.com) 